\title{
Altered neuroinflammatory, arachidonic acid cascade and synaptic markers in postmortem Alzheimer's disease brain
}

\author{
JS Rao ${ }^{1,2}$, SI Rapoport ${ }^{1}$ and H-W Kim ${ }^{1,2}$
}

\begin{abstract}
Alzheimer's disease (AD), a progressive neurodegenerative disorder, is the leading cause of dementia in the elderly. A recent positron emission tomography imaging study demonstrated upregulated brain arachidonic acid (AA) metabolism in $A D$ patients. Further, a mouse model of $A D$ shows an increase in AA-releasing cytosolic phospholipase $A_{2}\left(C P L A_{2}\right)$ in brain, and a reduction in $\mathrm{CPLA}_{2}$ activity ameliorated cognitive deficits. These observations led us to hypothesize that there is an upregulation of $A A$ cascade and neuroinflammatory markers in the brain of $A D$ patients. To test this hypothesis, we measured protein and mRNA levels of AA cascade, neuroinflammatory and synaptic markers in postmortem frontal cortex from 10 AD patients and 10 age-matched controls. Consistent with our hypothesis, $A D$ frontal cortex showed significant increases in protein and $m R N A$ levels of $c P L A_{2}-I V A$, secretory sPLA - IIA, cyclooxygenase-1 and -2, membrane prostaglandin (PG) synthase-1 and lipoxygenase-

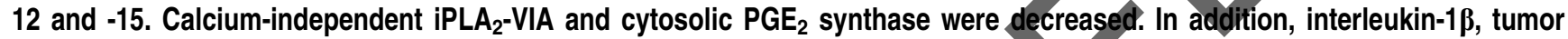
necrosis factor- $\alpha$, glial fibrillary acidic protein and CD11b were increased. AD postmortem brain also showed signs of cellular injury, including decreased synaptophysin and drebrin, pre- and postsynaptic markers. These results indicate that increased AA cascade and inflammatory markers could contribute to AD pathology. Altered brain AA cascade enzymes could be considered therapeutic targets for future drug development.
\end{abstract}

Translational Psychiatry (2011) 1, e31; doi:10.1038/tp.2011.27; published online 16 August 2011

\section{Introduction}

The postmortem Alzheimer's disease (AD) brain is characterized by intracellular neurofibrillary tangles with paired helical filaments consisting of phosphorylated $\tau$-protein, and extracellular senile (neuritic) plaques containing $\beta$-amyloid fibrils. In the United States, nearly 5.3 million people are affected by $\mathrm{AD}{ }^{1}$ Common behavioral disturbances, aside from memory loss, are apathy, depression, agitation and general withdrawal. Apathy is the most prevalent disturbance, affecting about $70 \%$ of $A D$ patients, depression ranks second, occurring in about $54 \%$ of patients, and agitation ranks third, appearing in about $50 \%$ of patients. ${ }^{2}$

The senile plaques often are infiltrated by activated microglia that secrete inflammatory cytokines, release nitric oxide and express peripheral benzodiazepine receptors. ${ }^{3-6}$ Inflammatory cytokines can activate many brain signaling pathways, including the arachidonic acid (AA, 20:4n-6) metabolic cascade. ${ }^{7}$ For example, activation of the cytokine interleukin (IL)-1 receptor cascade can increase expression of AA-metabolizing enzymes, including AA-selective cytosolic phospholipase $\mathrm{A}_{2}\left(\mathrm{CPLA}_{2}\right)$, secretory $\mathrm{SPLA}_{2}{ }^{8}$ and cyclooxygenase (COX)-2, ${ }^{9}$ and of the transcription factors activator protein (AP)-2 and/or nuclear factor kappa $B$ that regulate genetranscription of these enzymes. The released nitric oxide can also promote $A A$ hydrolysis from the membrane by $\mathrm{CPLA}_{2}$, by stimulating glutamate release from nerve terminals and thereby increasing intracellular $\mathrm{Ca}^{2+}$ concentrations via postsynaptic ionotropic $\mathrm{N}$-methyl-D-aspartate and other glutamatergic receptors. ${ }^{10,11} \beta$-Amyloid peptide can also provoke glutamate-induced excitotoxicity and $\mathrm{PLA}_{2}$ activation. ${ }^{12}$

AA is a conditionally essential polyunsaturated fatty acid found mainly in the stereospecifically numbered-2 position of membrane phospholipids, from which it can be hydrolyzed by $\mathrm{CPLA}_{2}$ or $\mathrm{SPLA}_{2}$. A portion of the released AA is metabolized to bioactive prostaglandin $\mathrm{H}_{2}\left(\mathrm{PGH}_{2}\right)$ by COX-1 or COX-2, to cytoprotective epoxyeicosatrienoic acid by cytochrome $\mathrm{p} 450$ epoxygenase, or to cytotoxic leukotrienes by lipoxygenase (LOX) subtypes-5, -12 and $-15 .{ }^{13}$ Bioactive $\mathrm{PGH}_{2}$ is converted to $\mathrm{PGE}_{2}$ (PGE) by membrane PG synthase-1 (mPGES-1) or cytosolic PG synthase (cPGES). $\mathrm{PGH}_{2}$ also can be converted to thromboxane $\mathrm{A}_{2}$ by thromboxane synthase (TXS)..$^{14}$ Of the two COX isoenzymes, COX-1 is constitutively expressed, whereas COX-2 is inducible. cPGES uses $\mathrm{PGH}_{2}$ produced by COX-1, whereas mPGES-1 uses COX-2-derived endoperoxide. ${ }^{15} \mathrm{AA}$ and its metabolites can modulate signal transduction, transcription, neuronal activity, apoptosis and many other processes within the brain. ${ }^{16-18}$

${ }^{1}$ Brain Physiology and Metabolism Section, National Institute on Aging, National Institutes of Health, Bethesda, MD, USA

Correspondence: Dr JS Rao, Brain Physiology and Metabolism Section, National Institute on Aging, National Institutes of Health, 9000 Rockville Pike, Building 9, Room 1S-126, Bethesda, MD 20892, USA.

E-mail: HTUjrao@mail.nih.gov

${ }^{2}$ These authors contributed equally to this work.

Keywords: Alzheimer's disease; arachidonic acid cascade; inflammation; synaptophysin; drebrin

Received 28 April 2011; revised 7 June 2011; accepted 16 June 2011 
Recent human imaging and postmortem studies have demonstrated an elevated AA incorporation coefficient $\left(k^{*}\right)$ as well as altered phospholipid fatty acid concentrations ${ }^{19}$ in brains of $A D$ patients, particularly in regions reported to have high densities of senile (neuritic) plaques with activated microglia. ${ }^{20}$ An increase in $k^{*}$ is suggestive of increased AA incorporation and utilization by the brain. AA utilization by the brain can be initiated by the release of $A A$ from the phospholipid membrane by $\mathrm{cPLA}_{2}$. Genetic deletion of $\mathrm{CPLA} 2$ has been shown to improve cognitive performance in a transgenic animal model of $A D .^{21}$ Moreover, drugs that decrease turnover and metabolites of the AA cascade, such as lithium and valproate, ${ }^{22}$ have been reported to have beneficial effects in patients with HIV-associated dementia. $^{23,24}$ Further studies have shown beneficial effects of lithium in $A D$ patients. ${ }^{25-27}$ These findings suggest that the AA cascade might have a role in the cognitive deficits associated with dementia.

In view of evidence of excitotoxicity and neuroinflammation in $A D,{ }^{28,29}$ and of elevated $A A$ metabolism in $A D$ patients, ${ }^{20}$ we hypothesized that the $A A$ cascade is upregulated in the $A D$ brain and is accompanied by elevated neuroinflammatory markers as well as by synaptic marker loss. To test this hypothesis in this study, protein and mRNA levels of $A A$ cascade enzymes, neuroinflammatory markers and synaptic markers were compared between postmortem frontal cortex from $10 \mathrm{AD}$ patients and 10 age-matched controls. We also compared expression of $\mathrm{Ca}^{2+}$-independent $\mathrm{iPLA}_{2}$, which is selective for docosahexaenoic acid (22:6n-3) in membrane phospholipid. ${ }^{30}$ The frontal cortex (Brodmann area 9) was chosen for study because functional and structural abnorm alities have been reported in this region in $A D$ patients $31-35$

\section{Materials and methods}

Postmortem brain samples. The protocol was approved by the Institutional Review Board of Mclean Hospital, and by the Office of Human Subjects Research of the National Institutes of Health (no. 4380). Frozen postmortem human frontal cortex (Brodmann area 9) from 10 AD patients (diagnosed by history and the presence of senile neuritic plaques and neurofibrillary tangles) and 10 age-matched controls was provided by the Harvard Brain Tissue Resource Center (McLean Hospital, Belmont, MA, USA) under PHS grant number R24MH068855 to JS Rao. Age (years, control: $70.20 \pm 2.4$ vs $A D: 70.60 \pm 2.4$ ), postmortem interval (hours, control: $19.16 \pm 1.0$ vs AD: $19.74 \pm 1.0$ ) and brain $\mathrm{pH}$ (control: $6.76 \pm 0.07$ vs $A D: 6.84 \pm 0.07$ ) did not differ significantly between the two groups, whereas the AD patients had been exposed to various psychotropic medications (Table 1).

Preparation of cytosolic fraction. Cytosolic and membrane extracts were prepared from postmortem frontal cortex of $A D$ and control subjects as reported. ${ }^{36}$ Frontal cortex tissue was homogenized in a homogenizing buffer containing $20 \mathrm{~mm}$ Tris- $\mathrm{HCl}$ (pH 7.4), 2 mM EGTA, $5 \mathrm{~mm}$ EDTA, $1.5 \mathrm{~mm}$ pepstatin, $2 \mathrm{~mm}$ leupeptin, $0.5 \mathrm{~mm}$ phenylmethylsulfonyl fluoride, $0.2 \mathrm{U} \mathrm{ml}^{-1}$ aprotinin and $2 \mathrm{~mm}$ dithiothreitol, using a Teflon homogenizer. The homogenate was centrifuged at
$100000 \mathrm{~g}$ for $60 \mathrm{~min}$ at $4{ }^{\circ} \mathrm{C}$. The resulting supernatant- 1 was the cytosolic fraction, and the pellet was resuspended in the homogenizing buffer containing $0.2 \%(\mathrm{w} / \mathrm{v})$ Triton $\mathrm{X}-100$. The suspension was kept at $4{ }^{\circ} \mathrm{C}$ for $60 \mathrm{~min}$ with occasional stirring and then centrifuged at $100000 \mathrm{~g}$ for $60 \mathrm{~min}$ at $4{ }^{\circ} \mathrm{C}$. The resulting supernatant- 2 was the membrane fraction. Protein concentrations in membrane and cytosolic fractions were determined with Protein Reagent (Bio-Rad, Hercules, CA, USA). The membrane and cytosolic fractions were confirmed using specific markers cadherin and tubulin, respectively.

Western blot analysis. Proteins $(50 \mu \mathrm{g})$ were separated on 4-20\% SDS-polyacrylamide gels (Bio-Rad). Following electrophoresis, the proteins were transferred to a polyvinylidene fluoride membrane (Bio-Rad). Protein blots were incubated overnight in Tris-buffered-saline, containing $5 \%$ non-fat dried milk and $0.1 \%$ Tween-20, with specific primary antibodies (1:200 dilution) for $\mathrm{CPLA}_{2}-\mathrm{IVA}, \mathrm{SPLA}_{2}-\mathrm{IIA}$, IPLA $_{2}-\mathrm{VIA}$, COX-1 (1:1000), COX-2 (1:500), cytochrome P450 epoxygenase, TXS, 5-, 12- and 15-LOX (Abcam, Cambridge MA, USA) and neuron-specific enolase (1:10000) mPGES-1(1:200), cPGES, IL-1beta (IL-1 $\beta$ ), tumor necrosis factor-alpha (TNF- $\alpha$ ) CD11b, and glial fibrillary acidic protein (GFAP). Synaptophysin, drebrin and mPGES-1 were determined using a specific (1:200) primary antibody (Abcam, Cambridge, MA, USA). Cytoplasmic protein blots were incubated with appropriate horseradish peroxidase-conjugated secondary antibodies (Bio-Rad) and were visualized using a chemiluminescence reaction (Kodak, Rochester, NY, USA). Optical densities of immunoblot bands were measured using Alpha Innotech Software (Alpha Innotech, San Leandro, CA, USA) and were normalized to $\beta$-actin (Sigma-Aldrich, St Louis, MO, USA) to correct for unequal loading. All experiments were carried out twice with 10 control and 10 postmortem brain samples from $A D$ patients. Values were expressed as percent of control.

Total RNA isolation and real time RT-PCR. Total RNA was isolated from the frontal cortex using an RNeasy mini kit (Qiagen, Valencia, CA, USA). RNA integrity number was measured using a Bioanalyzer (Agilent, Santa Clara, CA, USA). RNA integrity number values are control $6.80 \pm 0.65$ and AD $6.85 \pm 0.12$ (mean \pm s.e.m). Complementary DNA was prepared from total RNA using a high-capacity cDNA Archive kit (Applied Biosystems, Foster City, CA, USA). mRNA levels (cPLA ${ }_{2}$-IVA, sPLA ${ }_{2}$-IIA, iPLA ${ }_{2}-\mathrm{VIA}, \mathrm{COX}-1$, COX-2, m-PGES-1, cPGES, LOX-5, -12, -15, TXS, cytochrome p450 epoxygenase and neuron-specific enolase) were measured by quantitative RT-PCR, using an $A B I$ PRISM 7000 sequence detection system (Applied Biosystems). Specific primers and probes for cPLA $A_{2}-I V A$, sPLA $A_{2}-I A$, iPLA - -VIA, COX-1, COX-2, mPGES-1, cPGES, LOX-5, -12, -15, TXS, cytochrome P450 epoxygenase, IL-1 $\beta$, TNF- $\alpha$, CD11b, GFAP, synaptophysin and drebrin were purchased from TaqMan ${ }^{\circledR}$ gene expression assays (Applied Biosystems), and consisted of a $20 \times$ mix of unlabeled PCR primers and Taqman minor groove binder probe (FAM dye-labeled, Applied Biosystems). The fold-change in gene expression was determined by the $\Delta \Delta C_{\mathrm{T}}$ method. $^{37}$ Data are expressed as the relative level of the target gene 
Table 1 Characteristics of control subjects and patients with Alzheimer's disease

\begin{tabular}{|c|c|c|c|c|c|c|c|}
\hline Group & $\begin{array}{c}\text { Age } \\
\text { (years) }\end{array}$ & Sex & PMI (h) & Cause of death & Medications & $\begin{array}{l}\text { Disease } \\
\text { stage }\end{array}$ & Genotype \\
\hline Control & 60 & $\mathrm{~F}$ & 21 & Cardiopulmonary attack & Aspirin & & $\begin{array}{l}\text { ApoE2/4/ } \\
\text { ApoE2/3 }\end{array}$ \\
\hline Control & 80 & M & 15 & Myocardial infarction & Furosemide & & $\begin{array}{l}\text { ApoE2/4 } \\
\text { ApoE2/3 }\end{array}$ \\
\hline Control & 79 & $\mathrm{~F}$ & 19 & Cardiopulmonary attack & Isosorbide & & $\begin{array}{l}\text { ApoE2/4 } \\
\text { ApoE2/3 }\end{array}$ \\
\hline Control & 72 & $M$ & 22 & Cardiopulmonary attack & Atorvastatin & & $\begin{array}{l}\text { ApoE2/4 } \\
\text { ApoE2/3 }\end{array}$ \\
\hline Control & 64 & $M$ & 15 & $\begin{array}{l}\text { Acute myocardial } \\
\text { infarction }\end{array}$ & Vitamins & & $\begin{array}{l}\text { ApoE2/4 } \\
\text { ApoE2/3 }\end{array}$ \\
\hline Control & 74 & $\mathrm{M}$ & 18 & Cardiac arrest & Atenolol and digoxin & & $\begin{array}{l}\text { ApoE2/4 } \\
\text { ApoE2/3 }\end{array}$ \\
\hline Control & 61 & $\mathrm{M}$ & 22 & Myocardial infarction & Vitamins & & $\begin{array}{l}\text { ApoE2/4 } \\
\text { ApoE2/3 }\end{array}$ \\
\hline Control & 78 & $\mathrm{~F}$ & 17 & Myocardial infarction & Atorvastatin & & ApoE2/4 \\
\hline Control & 63 & M & 15 & Heart failure & Furosemide & & $\begin{array}{l}\text { ApoE2/4 } \\
\text { ApoE2/3 }\end{array}$ \\
\hline Control & 71 & M & 23 & Cardiac arrest & Aspirin & & $\begin{array}{l}\text { ApoE2/4 } \\
\text { ApoE2/3 }\end{array}$ \\
\hline$A D$ & 76 & $\mathrm{~F}$ & 25 & Stroke & Sertraline, carbamazepine, alendronate and aspirin & $\mathrm{V}$ & ApoE $4 / 4$ \\
\hline$A D$ & 83 & M & 17 & Stroke & Donepezil, valproate, tamsulosin and escitalopram & V & ApoE4/4 \\
\hline$A D$ & 72 & $\mathrm{M}$ & 24 & AD & Atenolol, donepezil, valproate and alprazolam & VI & ApoE4/4 \\
\hline$A D$ & 78 & $\mathrm{~F}$ & 17 & AD & Fexofenadine, donepezil and aspirin & $\mathrm{VI}$ & ApoE4/4 \\
\hline$A D$ & 75 & M & 15 & Atherosclerosis & $\begin{array}{l}\text { Gabapentin, furosemide, quetiapine and } \\
\text { escitalopram }\end{array}$ & $\mathrm{VI}$ & $\begin{array}{l}\text { ApoE2/4 } \\
\text { ApoE2/3 }\end{array}$ \\
\hline$A D$ & 66 & M & 23 & Broken hip and AD & Rivastigmine and donepezil & $\mathrm{V}$ & $\begin{array}{l}\text { ApoE2/4 } \\
\text { ApoE2/3 }\end{array}$ \\
\hline$A D$ & 63 & M & 18 & Pneumonia & pine, sertraline, aspirin and quetiapine & VI & ApoE2/4 \\
\hline$A D$ & 71 & M & 16 & End of $A D$ & $\begin{array}{l}\text { Atorvastatin, donepezil, pantoprazole, verapamil, } \\
\text { vitamin E and risperidone }\end{array}$ & $\mathrm{VI}$ & $\begin{array}{l}\text { ApoE2/4 } \\
\text { ApoE2/3 }\end{array}$ \\
\hline$A D$ & 61 & $\mathrm{~F}$ & 21 & End of $A D$ & ole, verapamil, vitamin $\mathrm{E}$ and risperidone & $\mathrm{VI}$ & $\begin{array}{l}\text { ApoE2/4 } \\
\text { ApoE2/3 }\end{array}$ \\
\hline$A D$ & 61 & M & 17 & Pneumonia & Valproate, quetiapine and olanzapine & $\mathrm{VI}$ & Not available \\
\hline
\end{tabular}

Abbreviations: AD, Alzheimer's disease; F, female; M, male; PMI, postmortem interval.

Not available, sample volume was not enough for this experiment; staging was done according to Reisberg et al. ${ }^{40}$

$\left(c P L A_{2}, s P L A_{2}, i P L A_{2}\right.$, COX-1, COX-2, m-PGES-1, cPGES, LOX-5, -12, -15, TXS, cytochrome $P 450$ epoxygenase, $I L-1 \beta, T N F-\alpha, C D 11 b, G F A P$, synaptophysin and drebrin) in the postmortem AD brain normalized to the endogenous control ( $\beta$-globulin) and relative to the control (calibrator), as previously described. ${ }^{38}$ All experiments were carried out twice in triplicate with 10 controls and 10 postmortem $A D$ brain samples and data are expressed as relative expression.

Statistical analysis. Data are expressed as mean \pm s.e.m. Statistical significance of means was calculated using a twotailed unpaired $t$-test. Pearson correlations were made between age, postmortem interval and $\mathrm{pH}$ of the frontal cortex, and mRNA levels of $\mathrm{SPLA}_{2}$, iPLA $2, \mathrm{COX}-1, \mathrm{COX}-2$, m-PGES-1, cPGES, LOX-5, -12, -15, TXS, cytochrome P450 epoxygenase, IL-1 $\beta$, TNF- $\alpha, \mathrm{CD} 11 \mathrm{~b}$ and GFAP in postmortem brain from controls and $A D$ patients, separately. Statistical significance was set at $P<0.05$.

\section{Results}

Upregulated protein and mRNA levels of $\mathbf{c P L A}, \mathrm{APLA}_{2}$ and COX-2. Mean protein levels of $\mathrm{CPLA}_{2}-\mathrm{IVA}$ and SPLA $\mathrm{2}_{2}$ IIA were increased significantly by $123 \%(P<0.001)$ and
$87 \%(P<0.01)$, respectively (Figures $1 \mathrm{a}$ and $\mathrm{b})$, in AD compared with control frontal cortex, whereas the mean $\mathrm{PLA}_{2}$ VIA protein level was decreased significantly by $-30 \%$ $(P<0.05)$ compared with controls (Figure 1c). Mean mRNA levels of $\mathrm{CPLA}_{2}$-IVA and SPLA $\mathrm{A}_{2}$ IIA were increased significantly in $A D$ compared with control brain by 4.6-fold $(P<0.01)$ and by fourfold $(P<0.01)$, respectively (Figures $1 d$ and $e)$, whereas iPLA ${ }_{2}-$ VIA mRNA was significantly decreased by 0.6 -fold $(P<0.05)$ (Figure 1f). COX-2 protein and mRNA levels were increased significantly by $79 \%$ (Figure 2a, $P<0.01$ ) and threefold (Figure 2c, $P<0.01$ ), respectively, whereas COX-1 protein was significantly increased by $24 \%$ (Figure $2 \mathrm{~b}, P<0.05$ ), without a significant change of the mRNA level (Figure 2d), in the AD cortex compared with control.

Increased protein and mRNA levels of MPGES-1. Statistically significant increases were found in mPGES-1 protein (by $82 \%, P<0.01$, Figure $2 \mathrm{e}$ ) and mRNA levels (by 3.1-fold, $P<0.01$, Figure 2g) in AD patients compared with controls. Mean protein (by 65\%, $P<0.01$, Figure 2f) and mRNA (by 0.32 -fold, $P<0.01$, Figure $2 \mathrm{~h}$ ) levels of cPGES were significantly decreased in $A D$ patients compared with controls. 

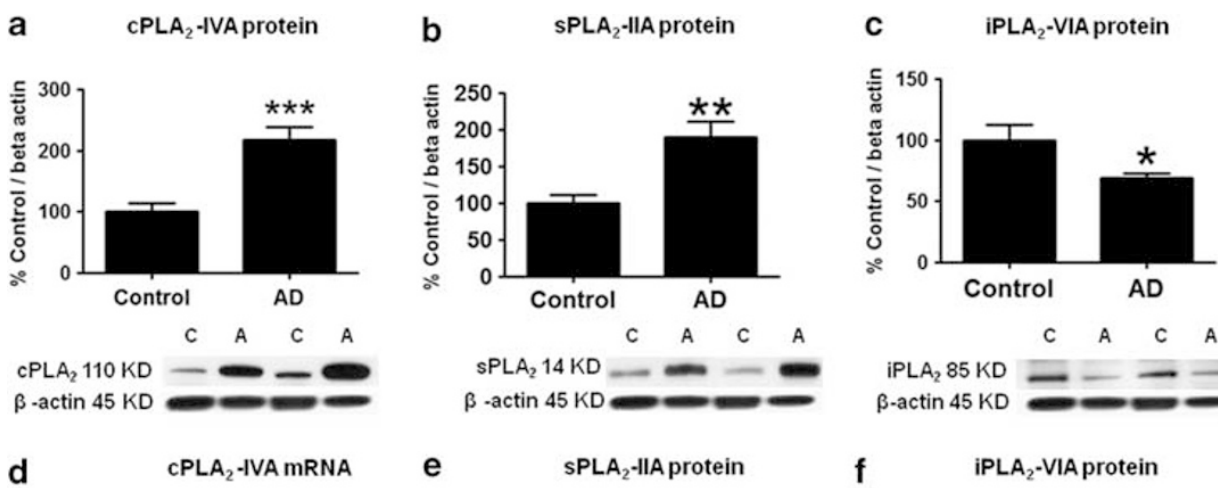

d

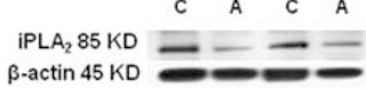

e

SPLA $A_{2}$-IA protein

f

iPLA - -VIA protein
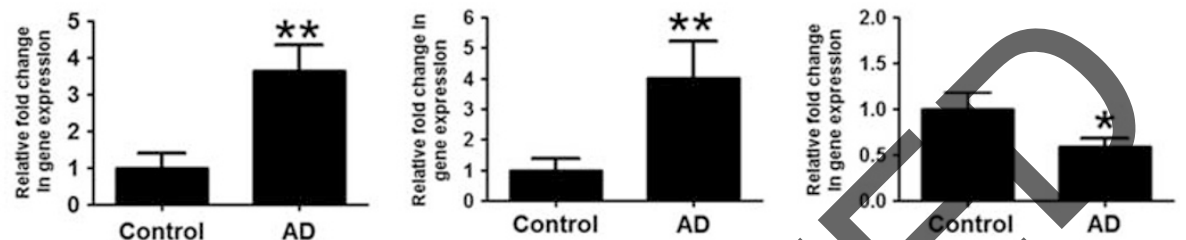

Figure $1 \operatorname{Mean~} \mathrm{cPLA}_{2}(\mathbf{a}), \mathrm{sPLA}_{2}(\mathbf{b})$ and $\mathrm{PLA} \mathrm{A}_{2}$ (c) protein (with representative immunoblots) as percent of control in frontal cortex, from control $(n=10)$ and $\mathrm{AD}(n=10)$ subjects. Data are optical densities relative to that of $\beta$-actin. Mean $m R N A$ as percent of control of $c P L A_{2}(d) . S P L A_{2}(e)$ and PLA $_{2}$ (f) in frontal cortex from control ( $\left.n=10\right)$ and $\mathrm{AD}(n=10)$ subjects, measured using RT-PCR. Data are normalized to the endogenous control ( $\beta$-globulin) and expressed relative to the control (calibrator), using the $\Delta \Delta C_{\text {T }}$ method. Mean \pm s.e.m., ${ }^{\star} P<0.05,{ }^{\star \star} P<0.01$ and ${ }^{\star \star \star} P<0.001$.

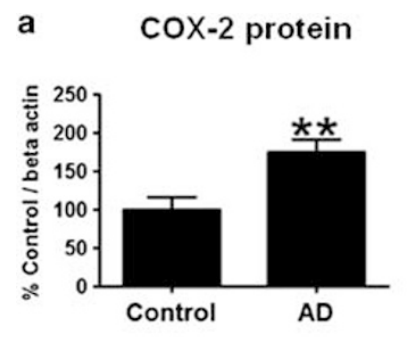

b coX-1 protein
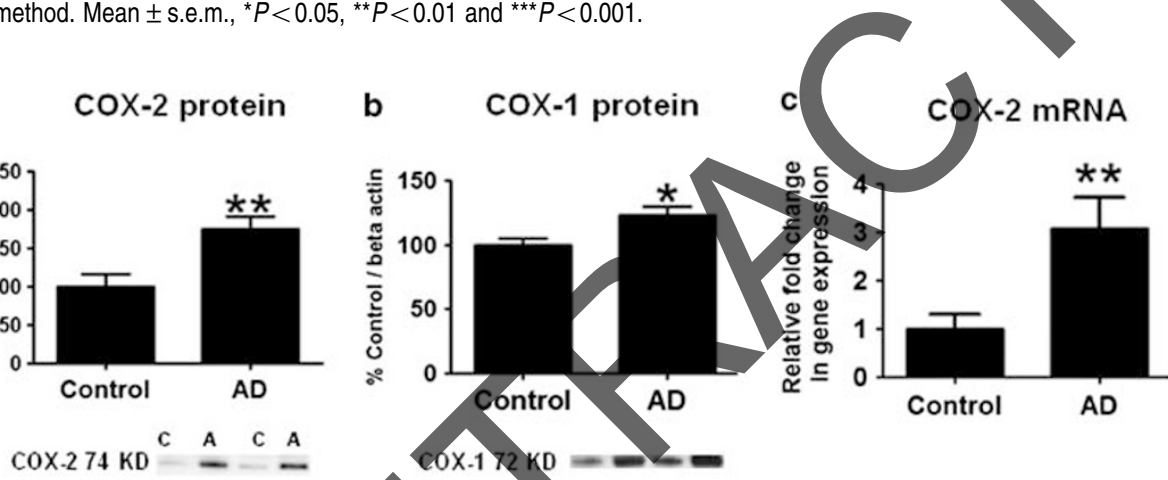

Control

$A D$

d

COX-1 mRNA

$\beta$-actin $45 \mathrm{KD}=-\infty-$

$\beta$-actin $45 \mathrm{KD}--$

e mPGES-1 Protein

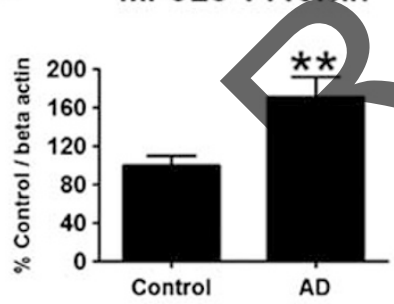

mPGES.1 (16 KD) $\stackrel{\mathrm{C}}{=} \stackrel{\mathrm{C}}{=}$

$\beta$-actin $(45 \mathrm{KD})$

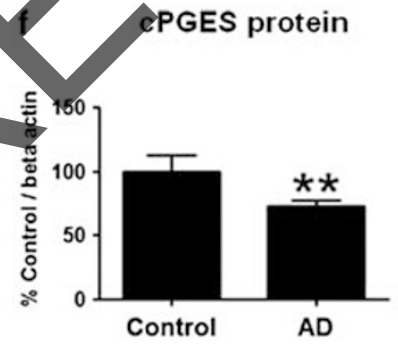

g

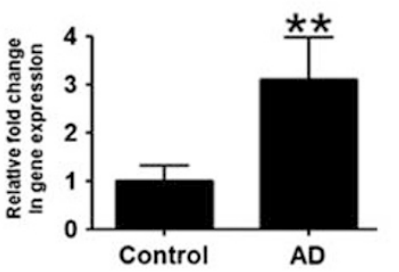

h

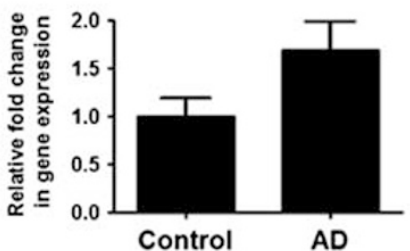

Figure 2 Mean COX-2 (a), COX-1 (b), mPGES-1 (e) and cPGES-2 (f) protein (with representative immunoblots) as percent of control in frontal cortex, from control $(n=10)$ and $\mathrm{AD}(n=10)$ subjects. Data are optical densities with relative to that of $\beta$-actin. COX-2 (c), COX-1 (d) mPGES-1 (g) and cPGES-2 (h) mRNA levels in the frontal cortex from controls $(n=10)$ and AD patients $(n=10)$, measured using RT-PCR. Data are normalized to the endogenous control ( $\beta$-globulin) and expressed with relative to the control (calibrator), using the $\Delta \Delta C_{T}$ method. Mean \pm s.e.m., ${ }^{*} P<0.05$ and ${ }^{* *} P<0.01$.

Increased protein and mRNA levels of 12- and 15-LOX. Mean protein levels of 12- and 15-LOX were increased significantly by $82 \%(P<0.01)$ and $35 \%(P<0.01)$, respectively,
(Figures $3 b$ and $c$ ), in $A D$ compared with control frontal cortex, whereas the mean 5-LOX protein level was not significantly altered between groups (Figure 3a). Mean mRNA 
Protein

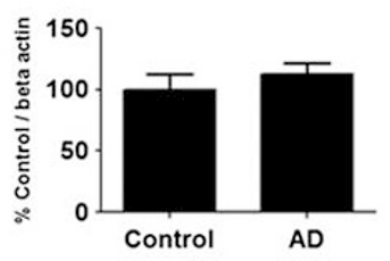

C A C A

$5 \mathrm{LOX}(78 \mathrm{KD})-\mathrm{F}=$

$\beta$-actin $(45$ KD) $=0=$ b

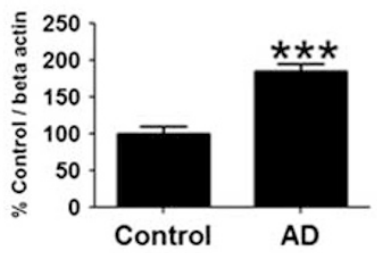

C $\mathrm{A} \quad \mathrm{C} A$
C

15-LOX

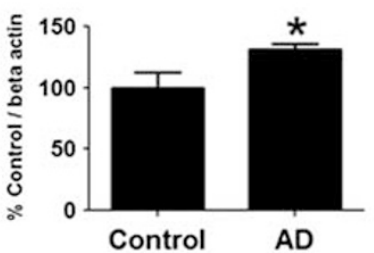

C A C A d p450 expoxygenase

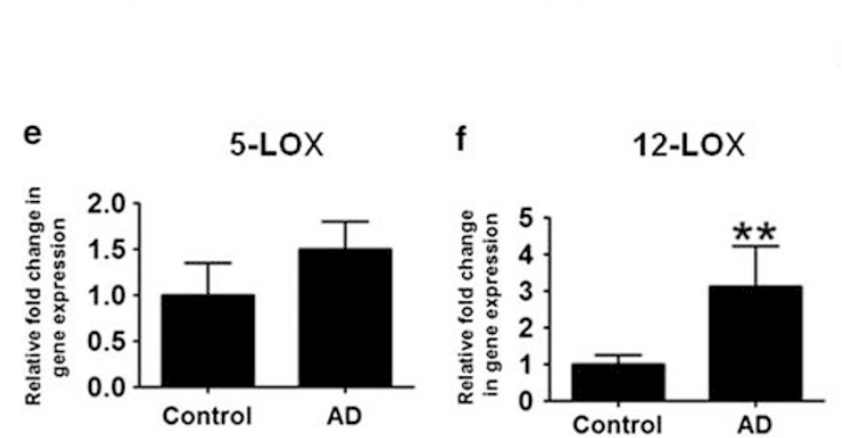

\section{mRNA}

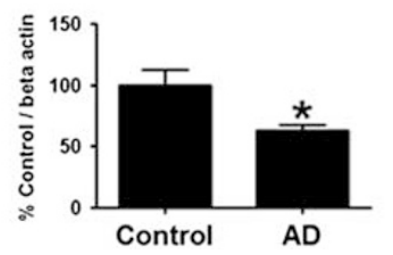

\section{$15 \operatorname{LOX}(75 \mathrm{KD})-\rightarrow \infty$}

P450 Epoxy.(75 KD) $\stackrel{\text { A C A }}{-}-$
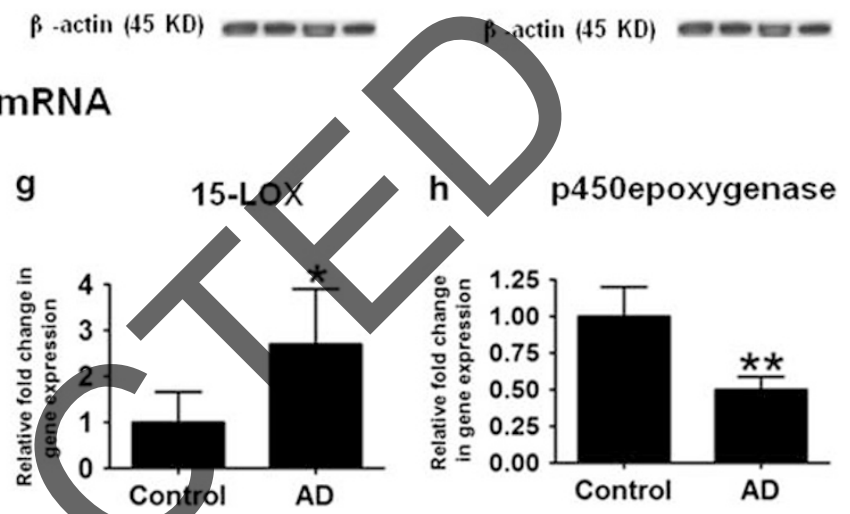

Figure 3 Mean 5-LOX (a), 12-LOX (b) 15-LOX (c) and p450 epoxygenase (d) protein levels (with representative immunoblots) in frontal cortex from control ( $n=10)$ and $\operatorname{AD}(n=10)$ subjects. Bar graphs are ratios of optical densities of LOXs and p450 epoxygenase to that of $\beta$-actin, expressed as percent of control. 5-LOX (e), 12-LOX (f) 15LOX (g) and p450 epoxygenase (h) mRNA levels in postmortem frontal cortex from the control $(n=10)$ and bipolar disorder $(n=10)$ subjects, measured using RT-PCR. Data are levels of LOXs and p450 epoxygenase in AD normalized to the endogenous control ( $\beta$-globulin) and relative to the control (calibrator), using the $\Delta \Delta C_{T}$ method. Mean \pm s.e.m., ${ }^{*} P<0.05,{ }^{\star \star} P<0.01,{ }^{* \star \star} P<0.001$.

levels of 12- and 15-LOX were increased significantly in $A D$ compared with control brain by threefold $(P<0.01)$ and 2.6 -fold $(P<0.05)$, respectively (Figures $3 f$ and $g$ ), whereas 5-LOX mRNA was not significantly changed $(P>0.05$, Figure $3 e)$.

Mean protein and mRNA levels of TXS did not differ significantly between $A D$ and control brain (data not shown). Mean protein (36\%) and mRNA (0.5-fold) levels of P450 epoxygenase were significantly reduced in $A D$ brains compared with controls (Figures $3 d$ and $h$ ).

Increased proinflammatory cytokines and markers of astrocytes and glia. Postmortem AD brains showed significantly elevated brain protein levels of inflammatory cytokines IL-1 $\beta$ (3.3-fold) and TNF- $\alpha$ (2.06-fold) compared with controls (Figures $4 a$ and $b$ ). These elevations corresponded to significantly increased mRNA levels of IL-1 $\beta$ (1.94-fold) and TNF- $\alpha$ (1.6-fold) (Figures 4c and d), respectively. Markers of astrocytes and glia, such as GFAP protein (149\%) and mRNA (2.89-fold), as well as the microglial markers CD11B protein (150\%) and mRNA (1.79-fold) were upregulated in postmortem $A D$ brain (Figures 4e and f).

Indications of cellular damage and loss. Protein and mRNA levels of synaptophysin and drebrin were decreased significantly in postmortem frontal cortex from $A D$ brain relative to control (Figures $5 a-d$ ). Mean protein and mRNA levels of neuron-specific enolase did not differ significantly between $A D$ and control brain (data not shown).

Correlations with brain variables. Pearson correlations between the protein and mRNA levels in AD brain treated separately on the one hand, and postmortem interval, age and $\mathrm{pH}$ on the other, were all statistically insignificant $(P>0.05)$ (Table 2). Mean values of the three parameters did not differ significantly between $A D$ and control groups.

\section{Discussion}

Frontal cortex from postmortem AD patients showed upregulated neuroinflammatory markers accompanied by disturbed AA cascade markers. The proinflammatory cytokines, IL-1 $\beta$ and TNF- $\alpha$, were increased, as were the microglial cell marker, CD11b and the astrocytic marker GFAP. Synaptophysin and drebrin, pre- and postsynaptic markers, were significantly decreased in AD brain. Together, these data support a role for upregulated $A A$ metabolism and cytokine production in association with neuronal damage in the AD brain.

Consistent with increased brain $A A$ incorporation in $A D$ patients, ${ }^{20}$ postmortem frontal cortex showed increased protein and mRNA levels of $\mathrm{CPLA}_{2}$-IVA compared with controls. Similar observations were reported in cerebral 
a

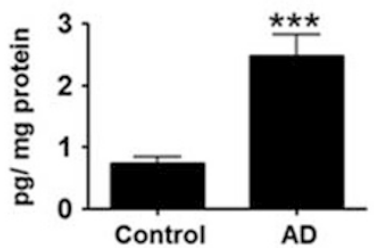

e
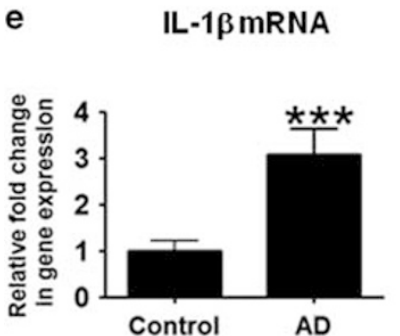

b TNF $\alpha$ protein

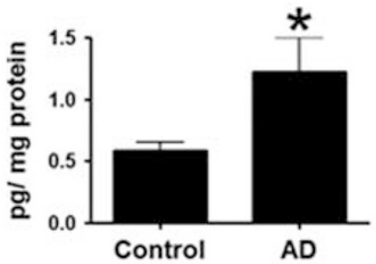

f c

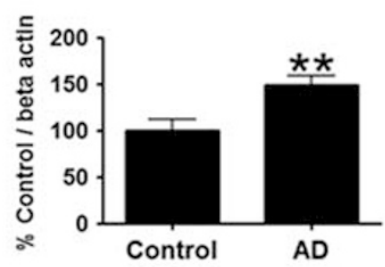

GFAP $\quad(48 \mathrm{KD}) \stackrel{\mathrm{C}}{=} \stackrel{\mathrm{C}}{=}=$
$\beta-\operatorname{actin}(45 \mathrm{KD})=-$ d CD11b protein

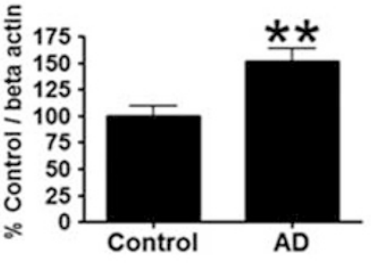

CD11b(128KD) C A C A

$\beta$-actin $(45 \mathrm{KD})=-$

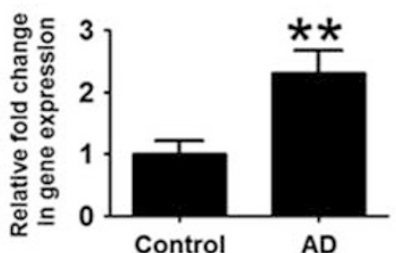

g

GFAP MRNA

h

CD11b MRNA

Figure 4 Mean IL-1 $\beta(\mathbf{a}), \operatorname{TNF}-\alpha(\mathbf{b})$, GFAP $(\mathbf{c})$ and CD11B (d) protein levels (with representative immunoblots) in frontal cortex from control $(n=10)$ and $\operatorname{AD}(n=10)$

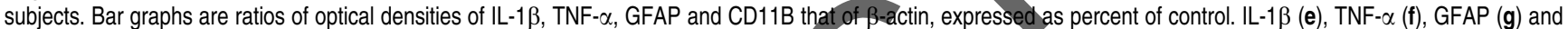
CD11B (h) mRNA levels in postmortem frontal cortex from the control $(n=10)$ and AD $(n=10)$ subjects, measured using RT-PCR. Data are levels of IL-1 $\beta$, TNF- $\alpha, G F A P$ and $\mathrm{CD} 11 \mathrm{~B}$ in $\mathrm{AD}$ normalized to the endogenous control ( $\beta$-globulin) and relative to the control (calibrator), using the $\Delta \Delta C_{\mathrm{T}}$ method. Mean \pm s.e.m., ${ }^{*} P<0.05$, ${ }^{* *} P<0.01$, ${ }^{* * *} P<0.001$.

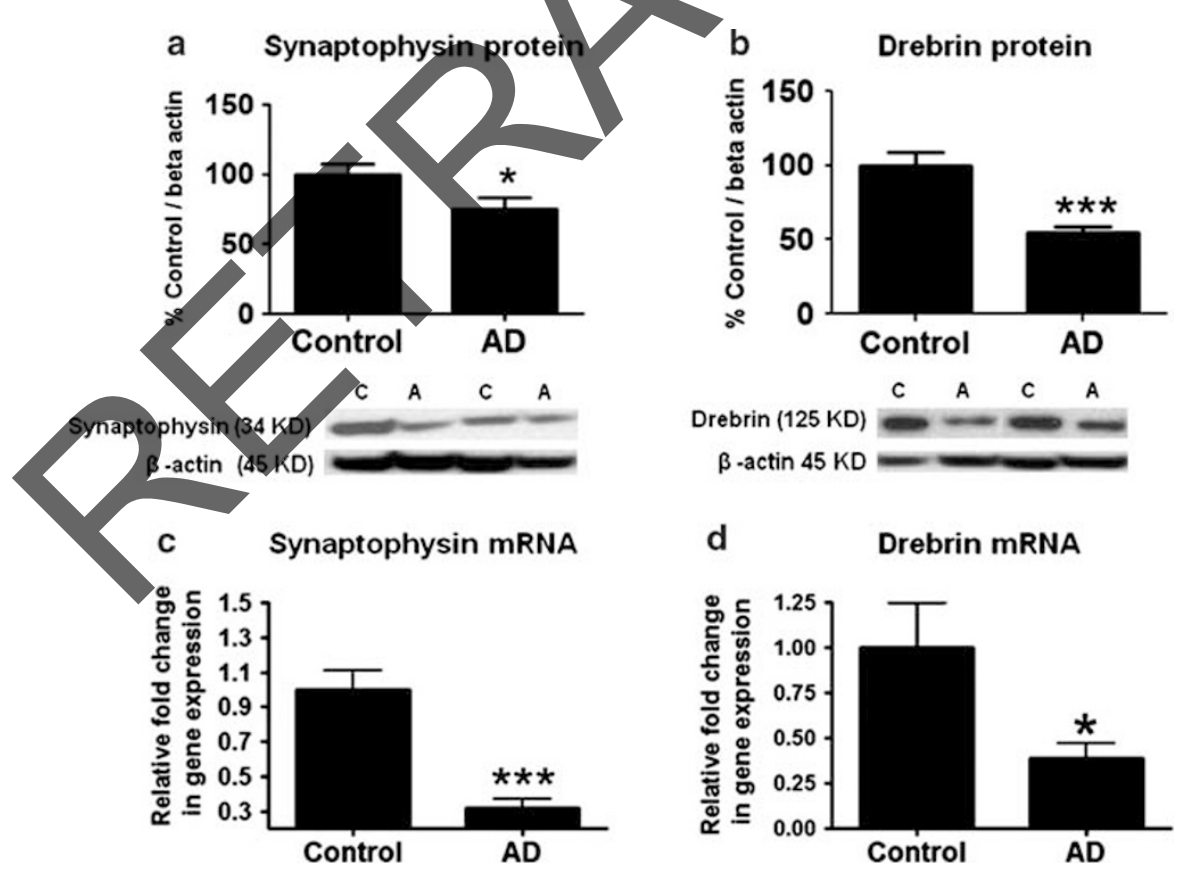

Figure 5 Mean synaptophysin (a) and drebrin (b) protein (with representative immunoblots) in control $(n=10)$ and $\operatorname{AD}(n=10)$ frontal cortex. Data are optical densities of synaptophysin and drebrin proteins to $\beta$-actin, expressed as percent of control. mRNA levels of synaptophysin and drebrin (c) in postmortem control ( $n=10)$ and $\operatorname{AD}(n=10)$ frontal cortex, measured using RT-PCR. Data are levels of synaptophysin and drebrin in the AD patients normalized to the endogenous control ( $\beta$-globulin) and relative to control level (calibrator), using the $\Delta \Delta C_{\mathrm{T}}$ method. Mean \pm s.e.m. and ${ }^{\star} P<0.05,{ }^{* \star \star} P<0.001$.

cortex $^{39}$ and hippocampal regions of postmortem AD brain. ${ }^{40}$ This increase could result from the presence of amyloid $\beta$. An earlier in vitro study demonstrated that treatment with low concentrations of soluble amyloid $\beta(1-40)$ or amyloid $\beta$ (1-42) peptide of rat cortical neurons resulted in an early calcium-dependent release of AA associated with a transient 
Table 2 Probabilities and Pearson correlation between brain protein and mRNA levels and subject age, postmortem intervals and $\mathrm{pH}$

\begin{tabular}{|c|c|c|c|c|c|c|}
\hline & \multicolumn{2}{|c|}{ Age } & \multicolumn{2}{|c|}{ PMI } & \multicolumn{2}{|c|}{$p H$} \\
\hline & P-value & $R 2$ & P-value & $R 2$ & P-value & $R 2$ \\
\hline \multicolumn{7}{|l|}{ Protein } \\
\hline $\mathrm{CPLA}_{2}$ & 0.589 & 0.02 & 0.617 & 0.0142 & 0.151 & 0.111 \\
\hline $\mathrm{sPLA}_{2}$ & 0.152 & 0.11 & 0.856 & 0.0019 & 0.238 & 0.076 \\
\hline $\mathrm{iPLA}_{2}$ & 0.812 & 0.00 & 0.779 & 0.0045 & 0.180 & 0.097 \\
\hline COX-1 & 0.417 & 0.04 & 0.673 & 0.0101 & 0.163 & 0.105 \\
\hline COX-2 & 0.498 & 0.03 & 0.409 & 0.0381 & 0.728 & 0.007 \\
\hline MPGES & 0.892 & 0.00 & 0.253 & 0.0718 & 0.367 & 0.045 \\
\hline cPGES & 0.768 & 0.00 & 0.938 & 0.0003 & 0.125 & 0.126 \\
\hline 12-LOX & 0.089 & 0.00 & 0.914 & 0.0010 & 0.613 & 0.022 \\
\hline 15-LOX & 0.640 & 0.01 & 0.443 & 0.0350 & 0.139 & 0.124 \\
\hline p450 Epoxy & 0.091 & 0.15 & 0.997 & 0.0000 & 0.235 & 0.077 \\
\hline TNF- $\alpha$ & 0.432 & 0.03 & 0.341 & 0.0505 & 0.243 & 0.096 \\
\hline IL-1 $1 \beta$ & 0.988 & 0.00 & 0.881 & 0.0013 & 0.898 & 0.001 \\
\hline Cd11b & 0.998 & 0.00 & 0.828 & 0.0027 & 0.879 & 0.001 \\
\hline GFAP & 0.357 & 0.05 & 0.277 & 0.0733 & 0.979 & 0.000 \\
\hline SYP & 0.572 & 0.02 & 0.345 & 0.0497 & 0.845 & 0.002 \\
\hline Drebrin & 0.323 & 0.05 & 0.545 & 0.0208 & 0.203 & 0.089 \\
\hline \multicolumn{7}{|l|}{$m R N A$} \\
\hline $\mathrm{CPLA}_{2}$ & 0.800 & 0.00 & 0.120 & 0.120 & 0.520 & 0.027 \\
\hline $\mathrm{SPLA}_{2}$ & 0.120 & 0.12 & 0.790 & 0.000 & 0.410 & 0.030 \\
\hline $\mathrm{iPLA}_{2}$ & 0.270 & 0.06 & 0.180 & 0.090 & 0.100 & 0.130 \\
\hline $\operatorname{cox}-1$ & 0.960 & 0.00 & 0.460 & 0.020 & 0.610 & 0.010 \\
\hline COX-2 & 0.330 & 0.05 & 0.300 & 0.050 & 0.070 & 0.160 \\
\hline MPGES & 0.900 & 0.00 & 0.380 & 0.042 & 0.700 & 0.000 \\
\hline cPGES & 0.350 & 0.04 & 0.880 & 0.000 & 0.190 & 0.090 \\
\hline 12-LOX & 0.350 & 0.04 & 0.200 & 0.080 & 0.190 & 0.090 \\
\hline 15-LOX & 0.490 & 0.02 & 0.420 & 0.030 & 0.690 & 0.000 \\
\hline p450 Epoxy & 0.430 & 0.03 & 0.410 & 0.030 & 0.960 & 0.000 \\
\hline TNF- $\alpha$ & 0.780 & 0.00 & 0.340 & 0.050 & 0.150 & \\
\hline IL-1 $\beta$ & 0.310 & 0.09 & 0.950 & 0.000 & 0.580 & 0.020 \\
\hline Cd11b & 0.620 & 0.01 & 0.790 & 0.000 & 0.860 & \\
\hline GFAP & 0.350 & 0.05 & 0.270 & 0.070 & & 0.00 \\
\hline SYP & 0.810 & 0.00 & 0.730 & 0.000 & 650 & 0.010 \\
\hline Drebrin & 0.170 & 0.16 & 0.630 & & & \\
\hline
\end{tabular}

Abbreviations: COX, cyclooxygenase; CPGES, cytosolic prostaglandin synthase; $c P L A_{2}$, cytosolic phospholipase $A_{2}$, GFAP, glial fibrillary acidic protein; iPLA, calcium-independent phospholipase $A_{2}, L O X$, lipoxygenase mPGES, membrane prostaglandin synthase, p450 epoxy, cytochrome p450 epoxygenase; $\mathrm{sPLA}$, secretory phospholipase $\mathrm{A}_{2}$; TNF- $\alpha$, tumor necrosis factor-alpha; SYP, synaptophysin.

relocalization of $\mathrm{ePLA}_{2}{ }^{41}$ Another calcium-dependent AA-releasing enzyme SPLA $A_{2}$ was also increased in postmortem AD brain. An increase also was reported in postmortem hippocampus and in cerebrospinal fluid from AD patients. ${ }^{42,43}$ Again this could result from the presence of $\beta$-amyloid peptide in the $A D$ brain. ${ }^{12}$ Frontal cortex calcium-independent iPLA ${ }_{2}-\mathrm{VIA}$ protein and mRNA levels were significantly decreased in the AD brain. This enzyme will release another important $n-3$ polyunsaturated fatty acid, docosahexaenoic acid, from membrane phospholipid. Similar dysregulation of $\mathrm{IPLA}_{2}$ was seen in $\mathrm{n}-3$ polyunsaturated fatty acid-deprived rats as well as in iPLA $_{2}$ knockout mice. ${ }^{44,45}$ A significant decrease in $\mathrm{PLA}_{2}$ expression in $\mathrm{AD}$ might have relevance to the report of a mutated $i P L A_{2}$ gene in neurodegenerative disorders. ${ }^{46}$

AA is metabolized to $\mathrm{PGH}_{2}$ by $\mathrm{COX}-1$ and $\mathrm{COX}-2$. COX-1 is constitutive, whereas COX-2 is an inducible enzyme. Protein levels of both enzymes were significantly increased in $A D$ brain without a significant change in COX-1 mRNA. $\mathrm{PGH}_{2}$ is further metabolized to $\mathrm{PGE}_{2}$ by $\mathrm{mPGES}$ and $\mathrm{cPGES}$. Protein and $\mathrm{mRNA}$ levels of $\mathrm{mPGES}$ were significantly increased with significant decreases in CPGES protein and mRNA levels in the $A D$ brain. Consistent with these findings, studies have demonstrated increased hippocampal COX-1 and frontal cortex COX-2 levels in the AD brain. ${ }^{47}$ The product of mPGES enzyme, $\mathrm{PGE}_{2}$, was also reported to increase in cerebrospinal fluid from AD patients. ${ }^{48}$ These changes could arise from the presence of $\beta$-amyloid peptide in the brain. ${ }^{49-51}$ A recent study also indicates reduced immunoreactivity to the $P G$ transporter in postmortem frontal cortex of AD patients. ${ }^{52}$ These changes could lead to an increased proinflammatory product $\mathrm{PGE}_{2}$.

$\mathrm{AA}$ is also channeled to other bioactive metabolites by LOXs such as 5-, 12- and 15-LOX. The protein and mRNA levels of LOXs 12 and 15 (type 1) were significantly increased in $\mathrm{AD}$ brain. Consistent with this observation, the postmortem AD brain showed elevated immunoreactivity to LOX12/15 and levels of 12/15-hydroxyeicosatetraenoic acids, metabolic products of 12/15-LOX in frontal cortex and temporal regions. ${ }^{53}$ These increases directly correlated with brain lipid peroxidation. ${ }^{53}$ Frontal cortex 5-LOX was not changed significantly in AD brain compared with control. In contrast, a reduced hippocampal 5-LOX immunoreactivity was reported in $A D$ brain. ${ }^{54}$ This discrepancy might be related to regional differences. The other $A A$ cascade markers, protein and mRNA levels of TXS, were not significantly changed postmortem AD brain. The protein and mRNA levels of cytochrome p450 epoxygenase were significantly reduced in AD brain compared with control. Given that epoxyeicosatrienoic acid produced by this enzyme can be neuroprotective, ${ }^{55,56}$ the reduced brain protein and mRNA levels of cytochrome p450 epoxygenase in AD may reflect a loss of neuroprotective processes.

The increase in AA cascade markers could result from increase in proinflammatory cytokines including $\mathrm{IL}-1 \beta$ and TNF- $\alpha$. This notion, based on studies that $\beta$-amyloid may cause AA release by stimulating microglia, could have led to the secretion of $\mathrm{IL}-1 \beta$ and $\mathrm{TNF}-\alpha,{ }^{57,58}$ and secondary increased transcription of $C P L A_{2}-I V A, S P L A_{2}-I A$, and COX-2. Cell culture studies have shown that both IL-1 $\beta$ and TNF- $\alpha$ can induce transcription of $c P L A_{2}, s P L A_{2}$ and $C O X-2$ genes in a nuclear factor-kappa B-dependent manner, ${ }^{59-62}$ as nuclear factor-kappa B binding sites are present on the promoter regions of these genes. ${ }^{63-65}$

$A D$ brain shows decreases in drebrin protein and mRNA levels compared with controls. The decreased protein and mRNA levels of the postsynaptic marker, drebrin, suggest synaptic loss, and studies indicate an association between lower brain drebrin levels and an increased risk of dementia in humans, ${ }^{66-69}$ including patients with AD. ${ }^{70}$ Similarly, drebrin is decreased in other psychiatric illnesses such as bipolar disorder and schizophrenia, in which neurocognitive impairments are common. ${ }^{71}$

Elevated IL-1 $\beta$ and TNF- $\alpha$ levels and increased expression of AA cascade enzymes have been implicated in the initiation of neuronal damage, ${ }^{16}$ contributing to cognitivebehavioral impairment in AD. A transgenic mouse model of $A D$ showed elevated levels of $\mathrm{CPLA}_{2}$, and $\mathrm{CPLA} \mathrm{A}_{2}$ inhibition or deletion improved cognitive performance. ${ }^{21}$ These observations support the notion that selective inhibition of neuroinflammatory and AA cascade pathways may alleviate 
cognitive impairment. Some clinical studies indicate that mood stabilizers such as lithium and sodium valproate are beneficial in HIV-1-associated dementia patients, ${ }^{23,24}$ and both of these agents attenuated neuroinflammationand $N$-methyl-D-aspartate-induced upregulated AA cascade markers in rat brain. ${ }^{10,72,73} \mathrm{~A}$ preliminary imaging study shows that AA metabolism is widely elevated in the AD brain, particularly in regions reported to have high densities of senile (neuritic) plaques with activated microglia. To the extent that the elevations represent upregulated AA metabolism associated with neuroinflammation, positron emission tomography with 1-(11)C-AA could be used to examine neuroinflammation in patients with $A D$ and other brain diseases. ${ }^{20,74}$ If correct, an increased AA image would be a biological marker of disease progression and could be used to evaluate therapeutic efficacy.

The AA cascade changes in the AD brain partly overlap changes reported in postmortem brain of bipolar disorder patients, in which excitotoxicity and neuroinflammation are considered to have a role. ${ }^{75}$ In bipolar disorder, brain $\mathrm{CPLA}_{2}$, sPLA $_{2}$ and COX-2 expression are upregulated. ${ }^{75}$ Thus, the changes noted here may not be specific to $A D$, but be more generally related to excitotoxic and inflammatory processes that occur in multiple chronic and progressive neurodegenerative and neuropsychiatric disorders.

Pearson correlation showed that no mRNA or protein level in either $A D$ or control brains was correlated significantly with postmortem interval, brain $\mathrm{pH}$ or age of the subject, and mean values of these parameters did not differ significantly between the two groups. However, future studies should examine AA cascade markers in brains from patients with schizophrenia or with unipolar depression or Parkinson's disease to test for disease specificity.

In conclusion, AD brain showed upregulated neuroinflammatory and $A A$ cascade markers associated with loss of synaptic markers, which may have a role in cognitive impairment and progression of AD disease. The attenuation of $A A$ cascade-induced pathways may be a strategy to treat AD patients.

\section{Conflict of interest \\ The authors declare no conflict of interest.}

Acknowledgements. We thank the Harvard Brain Bank, Boston, MA, USA, for providing the postmortem brain samples under PHS grant number R24MH068855. This research was entirely supported by the Intramural Research Program of the National Institute on Aging, National Institutes of Health. We also thank Dr Eugene Streicher and the Fellows' Editorial Board at the National Institutes of Health for reviewing the manuscript.

1. Alzheimer's Association. Alzheimer's disease facts and figures. Alzheimers Dement 2010; 6: 1-74.

2. Frisoni GB, Rozzini L, Gozzetti A, Binetti G, Zanetti O, Bianchetti A et al. Behavioral syndromes in Alzheimer's disease: description and correlates. Dement Geriatr Cogn Disord 1999; 10: 130-138.

3. Banati RB. The immune response in the Alzheimer's disease brain. Biochem Soc Trans 1997; 25: 683-685.

4. Kreutzberg GW. Microglia: a sensor for pathological events in the CNS. Trends Neurosc 1996; 19: 312-318.
5. McGeer PL, McGeer EG. Glial cell reactions in neurodegenerative diseases: pathophysiology and therapeutic interventions. Alzheimer Dis Assoc Disord 1998; 12(Suppl 2): S1-S6.

6. Pahan K, Sheikh FG, Namboodiri AM, Singh I. Lovastatin and phenylacetate inhibit the induction of nitric oxide synthase and cytokines in rat primary astrocytes, microglia, and macrophages. J Clin Invest 1997; 100: 2671-2679.

7. Sun GY, Horrocks LA, Farooqui AA. The roles of NADPH oxidase and phospholipases A2 in oxidative and inflammatory responses in neurodegenerative diseases. $J$ Neurochem 2007; 103: 1-16.

8. Wesche H, Henzel WJ, Shillinglaw W, Li S, Cao Z. MyD88: an adapter that recruits IRAK to the IL-1 receptor complex. Immunity 1997; 7: 837-847.

9. Bauer MK, Lieb K, Schulze-Osthoff K, Berger M, Gebicke-Haerter PJ, Bauer J et al. Expression and regulation of cyclooxygenase-2 in rat microglia. Eur J Biochem 1997; 243: 726-731.

10. Basselin M, Chang L, Bell JM, Rapoport SI. Chronic lithium chloride administration attenuates brain NMDA receptor-initiated signaling via arachidonic acid in unanesthetized rats. Neuropsychopharmacology 2006; 31: 1659-1674.

11. Dennis EA. Diversity of group types, regulation, and function of phospholipase A2. J Biol Chem 1994; 269: 13057-13060.

12. Lehtonen JY, Holopainen JM, Kinnunen PK. Activation of phospholipase A2 by amyloid beta-peptides in vitro. Biochemistry 1996; 35: 9407-9414.

13. Funk CD. Prostaglandins and leukotrienes: advances in eicosanoid biology. Science 2001; 294: 1871-1875.

14. Needleman $P$, Minkes $M$, Raz A. Thromboxanes: selective biosynthesis and distinct biological properties. Science 1976; 193: 163-165.

15. Samuelsson B, Morgenstern R, Jakobsson PJ. Membrane prostaglandin E synthase-1: a novel therapeutic target. Pharmacol Rev 2007; 59: 207-224.

16. Paris D, Town T, Mullan M. Novel strategies for opposing murine microglial activation Neurosci Lett 2000; 278: 5-8.

17. Leslie JB, Watkins WD. Eicosanoids in the central nervous system. J Neurosurg 1985; 63 : 659-668.

8. O'Banion MiK. Cyclooxygenase-2: molecular biology, pharmacology, and neurobiology. Crit Rev Neurobiol 1999; 13: 45-82.

Igarashi M, Ma K, Gao F, Kim HW, Rapoport SI, Rao JS. Disturbed choline plasmalogen and phospholipid fatty acid concentrations in Alzheimer's disease prefrontal cortex. $J$ Alzheimer's Dis 2011; 24: 507-517.

20. Esposito G, Giovacchini G, Liow JS, Bhattacharjee AK, Greenstein D, Schapiro M et al. Imaging neuroinflammation in Alzheimer's disease with radiolabeled arachidonic acid and PET. J Nucl Med 2008; 49: 1414-1421.

21. Sanchez-Mejia RO, Newman JW, Toh S, Yu GQ, Zhou Y, Halabisky B et al. Phospholipase A2 reduction ameliorates cognitive deficits in a mouse model of Alzheimer's disease. Nat Neurosci 2008; 11: 1311-1318.

22. Rapoport SI. Arachidonic acid and the brain. J Nutr 2008; 138: 2515-2520.

23. Schifitto G, Peterson DR, Zhong J, Ni H, Cruttenden K, Gaugh M et al. Valproic acid adjunctive therapy for HIV-associated cognitive impairment: a first report. Neurology 2006; 66: 919-921.

24. Letendre SL, Woods SP, Ellis RJ, Atkinson JH, Masliah E, van den Brande G et al. Lithium improves HIV-associated neurocognitive impairment. AIDS 2006; 20: 1885-1888.

25. Brinkman SD, Pomara N, Barnett N, Block R, Domino EF, Gershon S. Lithium-induced increases in red blood cell choline and memory performance in Alzheimer-type dementia. Biol Psychiatry 1984; 19: 157-164.

26. Mendes CT, Mury FB, de Sa Moreira E, Alberto FL, Forlenza OV, Dias-Neto E et al. Lithium reduces Gsk3b mRNA levels: implications for Alzheimer disease. Eur Arch Psychiatry Clin Neurosci 2009; 259: 16-22.

27. Pomara N, Block R, Domino EF, Gershon S. Decay in plasma lithium and normalization in red blood cell choline following cessation of lithium treatment in two elderly individuals with Alzheimer-type dementia. Biol Psychiatry 1984; 19: 919-922.

28. Akiyama H. Inflammatory response in Alzheimer's disease. Tohoku J Exp Med 1994; 174 295-303.

29. Hynd MR, Scott HL, Dodd PR. Glutamate-mediated excitotoxicity and neurodegeneration in Alzheimer's disease. Neurochem Int 2004; 45: 583-595.

30. Strokin M, Sergeeva M, Reiser G. Role of $\mathrm{Ca} 2+-$ independent phospholipase A2 and n-3 polyunsaturated fatty acid docosahexaenoic acid in prostanoid production in brain: perspectives for protection in neuroinflammation. Int $J$ Dev Neurosci 2004; 22: 551-557.

31. Armstrong RA. Is the clustering of beta-amyloid (A beta) deposits in the frontal cortex of Alzheimer patients determined by blood vessels? Neurosci Lett 1995; 195: 121-124.

32. Armstrong RA, Cairns NJ, Lantos PL. Spatial distribution of diffuse, primitive, and classic amyloid-beta deposits and blood vessels in the upper laminae of the frontal cortex in Alzheimer disease. Alzheimer Dis Assoc Disord 1998; 12: 378-383.

33. Fischer B, Popa-Wagner A. [Alzheimer disease: involvement of the complement system in cell death. Gene expression of $\mathrm{C} 1 \mathrm{q}$ and $\mathrm{C} 3$ in the frontal cortex of patients with Alzheimer disease and control probands]. Fortschritte der Medizin 1996; 114: 161-163.

34. Nordberg A, Winblad B. Reduced number of $\left[{ }^{3} \mathrm{H}\right]$ nicotine and $\left[{ }^{3} \mathrm{H}\right]$ acetylcholine binding sites in the frontal cortex of Alzheimer brains. Neurosci Lett 1986; 72: 115-119. 
35. Soininen H, Kosunen O, Helisalmi S, Mannermaa A, Paljarvi L, Talasniemi S et al. A severe loss of choline acetyltransferase in the frontal cortex of Alzheimer patients carrying apolipoprotein epsilon 4 allele. Neurosci Lett 1995; 187: 79-82.

36. Dwivedi Y, Rizavi HS, Rao JS, Pandey GN. Modifications in the phosphoinositide signaling pathway by adrenal glucocorticoids in rat brain: focus on phosphoinositide-specific phospholipase C and inositol 1,4,5-trisphosphate. J Pharmacol Exp Ther 2000; 295: 244-254.

37. Rao JS, Harry GJ, Rapoport SI, Kim HW. Increased excitotoxicity and neuroinflammatory markers in postmortem frontal cortex from bipolar disorder patients. Mol psychiatry 2010; 15: 384-392.

38. Kim H-W, Lee HJ, Rapoport SI, Rao JS. Hyperglutamatergic state in postmortem frontal cortex of bipolar disorder patients. Soc Neurosci Abstr 2007; 707: 704/Z703.

39. Stephenson DT, Lemere CA, Selkoe DJ, Clemens JA. Cytosolic phospholipase A2 (cPLA2) immunoreactivity is elevated in Alzheimer's disease brain. Neurobiol Dis 1996; 3 $51-63$

40. Lukiw WJ, Cui JG, Marcheselli VL, Bodker M, Botkjaer A, Gotlinger K et al. A role for docosahexaenoic acid-derived neuroprotectin D1 in neural cell survival and Alzheimer disease. J Clin Invest 2005; 115: 2774-2783.

41. Kriem B, Sponne I, Fifre A, Malaplate-Armand C, Lozac'h-Pillot K, Koziel V et al. Cytosolic phospholipase A2 mediates neuronal apoptosis induced by soluble oligomers of the amyloid-beta peptide. FASEB J 2005; 19: 85-87.

42. Sun GY, Xu J, Jensen MD, Simonyi A. Phospholipase A2 in the central nervous system: implications for neurodegenerative diseases. J Lipid Res 2004; 45: 205-213.

43. Chalbot S, Zetterberg H, Blennow K, Fladby T, Grundke-labal I, Iqbal K. Cerebrospinal fluid secretory $\mathrm{Ca} 2+-$ dependent phospholipase A2 activity: a biomarker of blood-cerebrospinal fluid barrier permeability. Neurosci Lett 2010; 478: 179-183.

44. Rao JS, Ertley RN, DeMar Jr JC, Rapoport SI, Bazinet RP, Lee HJ. Dietary n-3 PUFA deprivation alters expression of enzymes of the arachidonic and docosahexaenoic acid cascades in rat frontal cortex. Mol Psychiatry 2007; 12: 151-157.

45. Basselin M, Rosa AO, Ramadan E, Cheon Y, Chang L, Chen M et al. Imaging decreased brain docosahexaenoic acid metabolism and signaling in $\mathrm{PLL}(2)$ beta $(\mathrm{VIA})$-deficient mice. $J$ Lipid Res 2010; 51: 3166-3173.

46. Morgan NV, Westaway SK, Morton JE, Gregory A, Gissen P, Sonek S et al. PLA2G6 encoding a phospholipase A2, is mutated in neurodegenerative disorders with high brain iron. Nat Genet 2006; 38: 752-754.

47. Pasinetti GM, Aisen PS. Cyclooxygenase-2 expression is increased in frontal cortex Alzheimer's disease brain. Neuroscience 1998; 87: 319-324.

48. Montine TJ, Sidell KR, Crews BC, Markesbery WR, Marnett LJ, Roberts II LJ et al Elevated CSF prostaglandin E2 levels in patients with probable AD. Neurology 1999; 53: 1495-1498.

49. Quadros A, Patel N, Crescentini R, Crawford F, Paris D, Mullan M. Increased TNFalpha production and Cox-2 activity in organotypic brain slice cultures from APPsw transgenic mice. Neurosci Lett 2003; 353: 66-68.

50. Hull M, Muksch B, Akundi RS, Waschbisch A, Hoozemans JJ, Veerhuis R et al. Amyloid beta peptide (25-35) activates protein kinase $C$ leading to cyclooxygenase-2 induction and prostaglandin E2 release in primary midbrain astrocytes. Neurochem Int 2006; 48: 663-672.

51. Hoshino T, Nakaya T, Homan T, Tanaka K, Sugimoto Y, Araki W et al. Involvement of prostaglandin E2 in production of amyloid-beta peptides both in vitroand in vivo. J Biol Chem 2007; 282: 32676-32688.

52. Choi K, Zhuang H, Crain B, Dore S. Expression and localization of prostaglandin transporter in Alzheimer disease brains and age-matched controls. J Neuroimmunol 2008; 195: 81-87.

53. Pratico D, Zhukareva V, Yao Y, Uryu K, Funk CD, Lawson JA et al. 12/15-lipoxygenase is increased in Alzheimer's disease; possible involvement in brain oxidative stress. Am J Pathol 2004; 164: 1655-1662

54. Ikonomovic MD, Abrahamson EE, Uz T, Manev H, Dekosky ST. Increased 5-lipoxygenase immunoreactivity in the hippocampus of patients with Alzheimer's disease. J Histochem Cytochem 2008; 56: 1065-1073.

55. lliff JJ, Jia J, Nelson J, Goyagi T, Klaus J, Alkayed NJ. Epoxyeicosanoid signaling in CNS function and disease. Prostaglandins Other Lipid Mediat 2010; 91: 68-84.

56. Caro AA, Cederbaum Al. Role of cytochrome P450 in phospholipase A2- and arachidonic acid-mediated cytotoxicity. Free Radic Biol Med 2006; 40: 364-375.

57. Lindberg C, Selenica ML, Westlind-Danielsson A, Schultzberg M. Beta-amyloid protein structure determines the nature of cytokine release from rat microglia. J Mol Neurosci2005; 27: $1-12$.
58. Chalimoniuk M, Stolecka A, Cakala M, Hauptmann S, Schulz K, Lipka U et al. Amyloid beta enhances cytosolic phospholipase A2 level and arachidonic acid release via nitric oxide in APP-transfected PC12 cells. Acta Biochim Pol 2007; 54: 611-623.

59. Vervoordeldonk MJ, Pineda Torra IM, Aarsman AJ, van den Bosch $\mathrm{H}$. Aspirin inhibits expression of the interleukin-1beta-inducible group II phospholipase A2. FEBS Lett 1996; 397: 108-112.

60. Hernandez M, Fuentes L, Fernandez Aviles FJ, Crespo MS, Nieto ML. Secretory phospholipase $A(2)$ elicits proinflammatory changes and upregulates the surface expression of fas ligand in monocytic cells: potential relevance for atherogenesis. Circ Res 2002; 90: 38-45

61. Bousserouel S, Brouillet A, Bereziat G, Raymondjean M, Andreani M. Different effects of n6 and $n-3$ polyunsaturated fatty acids on the activation of rat smooth muscle cells by interleukin-1 beta. J Lipid Res 2003; 44: 601-611.

62. Tran PO, Gleason CE, Robertson RP. Inhibition of interleukin-1beta-induced COX-2 and EP3 gene expression by sodium salicylate enhances pancreatic islet beta-cell function. Diabetes 2002; 51: 1772-1778.

63. Morri H, Ozaki M, Watanabe Y. 5'-flanking region surrounding a human cytosolic phospholipase A2 gene. Biochem Biophys Res Commun 1994; 205: 6-11.

64. Antonio V, Brouillet A, Janvier B, Monne C, Bereziat G, Andreani M et al. Transcriptional regulation of the rat type IIA phospholipase A2 gene by CAMP and interleukin-1beta in vascular smooth muscle cells: interplay of the CCAAT/enhancer binding protein (C/EBP), nuclear factor-kappaB and Ets transcription factors. Biochem J 2002; 368: 415-424.

65. Tanabe T, Tohnai N. Cyclooxygenase isozymes and their gene structures and expression. Prostaglandins Other Lipid Mediat 2002; 68-69: 95-114.

66. Kojima N, Shirao T. Synaptic dysfunction and disruption of postsynaptic drebrin-actin complex: a study of neurological disorders accompanied by cognitive deficits. Neurosci Res 2007; 5

67. Counts, SE, Nadeem M, Lad SP, Wuu J, Mufson EJ. Differential expression of synaptic proteins in the frontal and temporal cortex of elderly subjects with mild cognitive impairment. J Neuropathol Exp Neurol 2006; 65: 592-601.

Zhao L, Ma QL, Calon F, Harris-White ME, Yang F, Lim GP et al. Role of p21-activated kinase pathway defects in the cognitive deficits of Alzheimer disease. Nat Neurosci 2006; 9: 234-242.

69. KobayashiR, Sekino Y, Shirao T, Tanaka S, Ogura T, Inada K et al. Antisense knockdown of drebrin $A$, a dendritic spine protein, causes stronger preference, impaired pre-pulse inhibition, and an increased sensitivity to psychostimulant. Neurosci Res 2004; 49: 205-217.

70. Hatanpaa K, Isaacs KR, Shirao T, Brady DR, Rapoport SI. Loss of proteins regulating synaptic plasticity in normal aging of the human brain and in Alzheimer disease. J Neuropathol Exp Neurol 1999; 58: 637-643.

71. McIntosh AM, Moorhead TW, McKirdy J, Hall J, Sussmann JE, Stanfield AC et al. Prefrontal gyral folding and its cognitive correlates in bipolar disorder and schizophrenia. Acta Psychiatr Scand 2009; 119: 192-198.

72. Basselin M, Chang L, Chen M, Bell JM, Rapoport SI. Chronic administration of valproic acid reduces brain NMDA signaling via arachidonic acid in unanesthetized rats. Neurochem Res 2008; 33: 2229-2240.

73. Rapoport SI, Basselin M, Kim HW, Rao JS. Bipolar disorder and mechanisms of action of mood stabilizers. Brain Res Rev 2009; 61: 185-209.

74. Hampel H, Teipel SJ, Alexander GE, Pogarell O, Rapoport SI, Moller HJ In vivo imaging of region and cell type specific neocortical neurodegeneration in Alzheimer's disease. Perspectives of MRI derived corpus callosum measurement for mapping disease progression and effects of therapy. Evidence from studies with MRI, EEG and PET. J Neural Transm 2002; 109: 837-855.

75. Kim HW, Rapoport SI, Rao JS. Altered arachidonic acid cascade enzymes in postmortem brain from bipolar disorder patients. Mol Psychiatry 2011; 16: 419-428.

Translational Psychiatry is an open-access journal published by Nature Publishing Group. This work is licensed under the Creative Commons Attribution-Noncommercial-No Derivative Works 3.0 Unported License. To view a copy of this license, visit http://creativecommons.org/licenses/by-nc-nd/3.0/ 


\section{RETRACTION}

\section{Altered neuroinflammatory, arachidonic acid cascade and synaptic markers in postmortem Alzheimer's disease brain}

JS Rao ${ }^{1}$, SI Rapoport and H-W Kim ${ }^{1}$

Translational Psychiatry (2017) 7, e1127; doi:10.1038/tp.2017.97; published online 9 May 2017

Retraction to: Transl Psychiatry 2011; 1: e31. Published online 16 August 2011

The above article has been retracted by the editor because author Stanley I Rapoport alerted the editor, and the National Institutes of
Health subsequently confirmed, that the data represented by Figures 4 and 5 were falsified. Stanley I Rapoport and Hyung-Wook Kim support this retraction. The other author has not responded to our correspondence with them about the retraction of their article.

Brain Physiology and Metabolism Section, National Institute on Aging, National Institutes of Health, Bethesda, MD, USA. Correspondence: Dr JS Rao, Brain Physiology and Metabolism Section, National Institute on Aging, National Institutes of Health, 9000 Rockville Pike, Building 9, Room 1S-126, Bethesda, MD 20892, USA.

E-mail: HTUjrao@mail.nih.gov

${ }^{1}$ These authors contributed equally to this work. 